\title{
Species of Lepidoptera Defoliators of Eucalyptus as New Host for the Parasitoid Palmistichus elaeisis (Hymenoptera: Eulophidae)
}

\author{
Fabricio Fagundes Pereira ${ }^{1}$, Teresinha Vinha Zanuncio ${ }^{1}$, José Cola Zanuncio ${ }^{1}$, Dirceu \\ Pratissoli $^{2}$ and Marcelo Teixeira Tavares ${ }^{3}$ \\ ${ }^{1}$ Departamento de Biologia Animal; Universidade Federal de Viçosa; 36.571-000; zanuncio@ ufv.br; Viçosa - MG - \\ Brasil. ${ }^{2}$ Departamento de Fitotecnia; Universidade Federal do Espírito Santo; 29500-000; Alegre - ES - Brasil. \\ ${ }^{3}$ Departamento de Ciências Biológicas; Universidade Federal do Espírito Santo; 29.040-090; Vitória - ES - Brasil
}

\begin{abstract}
Pupae of Thyrinteina arnobia (Stoll) and Thyrinteina leucoceraea Rindge (Lepidoptera: Geometridae) were obtained from Eucalyptus cloeziana F. Muell and Eucalyptus urophylla S.T. Blake plants, respectively. Specimens of a parasitoid emerged from $\mathrm{T}$. arnobia pupae and also found parasitising T. leucoceraea pupae in the field were identified as Palmistichus elaeisis Delvare and LaSalle (Hymenoptera: Eulophidae). This is the first report on P. elaeisis parasitizing T. arnobia and T. leucoceraea pupae in natural conditions in Brazil. P. elaeisis also parasitized these hosts and Bombyx mori Linnaeus (Lepidoptera: Bombycidae), Anticarsia gemmatalis Hubner, Pseudaletia sequax Franclemont, Alabama argillacea Huebner (Lepidoptera: Noctuidae), Dirphia moderata Bouvier (Lepidoptera: Saturniidae) and Halysidota pearsoni Watson (Lepidoptera: Arctiidae) in the laboratory. The production and release of $\mathrm{P}$. elaeisis could be an efficient alternative for controlling Lepidoptera defoliators in eucalyptus plantations.
\end{abstract}

Key words: Eucalyptus, lepidopterous, parasitoid

Parasitoids are important due to their great diversity and high control levels that they inflict on host populations (Mussury and Fernandes, 2002; Pratissoli et al., 2005). Most of these natural enemies belong to the orders Hymenoptera and Diptera with, approximately, 50.000 species described for the first order (Godfray, 1994; Van Driesche and Bellows, 1996). Chalcidoidea and Ichneumonoidea are the most important groups of the Hymenoptera order in the forests where they parasitize eggs, larvae, pupae and adults of insects, mainly of the orders Coleoptera, Lepidoptera, Diptera and Homoptera (Berti Filho, 1985). The families Ichneumonidae, Braconidae, Scelionidae and Eulophidae have been the most abundant ones in eucalyptus plantations (Dall'Oglio et al., 2003). The family Eulophidae presents 283 genera and 3977 species in tropical and temperate areas as endoparasitoids or ectoparasitoids; idiobiontes or koinobiontes; solitary or gregarious; primary or hiperparasitoids; specialists or generalists and many of these species have been studied and used with success in programs of biological control (Noyes, 1998; Gauthier et al., 2000; Hansson, 2004). Tetrastichinae is the largest subfamily of Eulophidae with hosts in more than 100 families of insects of different orders (LaSalle, 1993; LaSalle and Schauff, 1995). A species of the

\footnotetext{
${ }^{*}$ Author for correspondence
} 
subfamily Tetrastichinae was described as Palmistichus elaeisis (Delvare and LaSalle, 1993). This parasitoid was found in Brazil in Eupseudosoma involuta (Sepp) (Arctiidae), Euselasia eucerus Hewitson (Riodinidae) (Delvare and LaSalle, 1993) and Sabulodes sp. (Geometridae) in eucalyptus plantations (Bittencourt and Berti Filho, 1999). P. elaeisis parasitized and developed in Diatraea saccharalis (Fabricius), Anticarsia gemmatalis Hubner, Heliothis virescens (Fabricius), Spodoptera frugiperda (Smith) (Noctuidae) and Thyrinteina arnobia (Stoll) (Geometridae) at $22^{\circ} \mathrm{C}$ in the laboratory (Bittencourt and Berti Filho, 1999; 2004).

Thyrinteina arnobia is reared on Eucalyptus cloeziana F. Muell plants in the Laboratory of Forest Entomology of the Federal University of Viçosa. Pupae of this species were collected and conditioned in plastic pots of $10 \mathrm{~cm}$ diameter by $12 \mathrm{~cm}$ height $(500 \mathrm{ml})$ with a screen in the center of its cover and maintained at $25 \pm 2^{\circ} \mathrm{C}$, relative humidity of $60 \pm 10 \%$ and photo phase of $12 \mathrm{~h}$. A total of 140 specimens of this parasitoid (first generation) emerged from one of these pupae were maintained in glass pots $(12.5$ diameter $x 17.0 \mathrm{~cm}$ height), labeled and covered with woven type organza with a honey drop inside to feed the adults at $25 \pm 2^{\circ} \mathrm{C}$, relative humidity of $70 \pm 10 \%$ and photo phase of $14 \mathrm{~h}$. Ten 24 to $72 \mathrm{~h}$ old T. arnobia pupae were used as host for the parasitoids. The

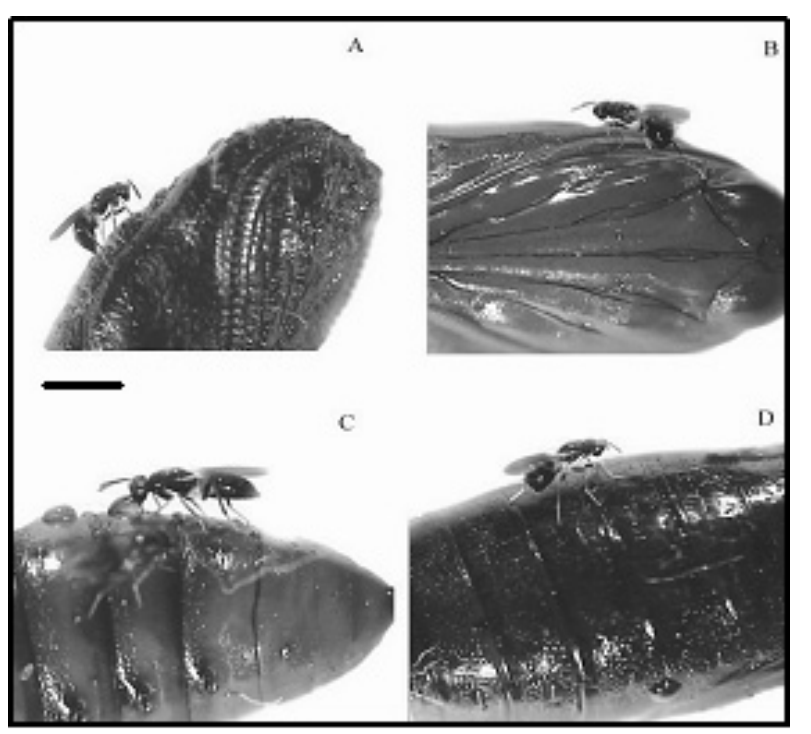

parasitoids were removed after $24 \mathrm{~h}$ and conditioned in alcohol (70\%). Forty specimens of this parasitoid were sent to Dr. Marcelo Teixeira Tavares, of the Department of Biological Sciences, of the Federal University of Espírito Santo and to Dr. Christer Hansson, Department of Zoology, Lund University, Sweden, for identification.

The insects were identified as Palmistichus elaeisis Delvare and LaSalle (Hymenoptera: Eulophidae). This was the first report of this species paratizing $T$. arnobia pupae in natural conditions in Brazil. The procedure of rearing $P$. elaeisis was repeated during five generations to guarantee the expression of the biological characteristics of this parasitoid in the laboratory. Twelve pupae of Thyrinteina leucoceraea Rindge (Lepidoptera: Geometridae), Bombyx mori Linnaeus (Lepidoptera: Bombycidae), Anticarsia gemmatalis Hubner, Pseudaletia sequax Franclemont, Alabama argillacea (Huebner), Spodoptera frugiperda (Smith) (Lepidoptera: Noctuidae), Dirphia moderata Bouvier (Lepidoptera: Saturniidae) and Halysidota pearsoni Watson (Lepidoptera: Arctiidae) (24 to $72 \mathrm{~h}$ old) were submitted to the parasitism by adults of sixth generation $P$. elaeisis. Besides the natural host $T$. arnobia (Fig. 1A), P. elaeisis parasitized pupae of $P$. sequax (Fig. 1B), $S$. frugiperda (Fig.1C), H. pearsoni (Fig. 1D), A. argillacea (Fig. E), A. gemmatalis (Fig. 1F), B. mori (Fig. 1G), and D. moderata (Fig. 1H).

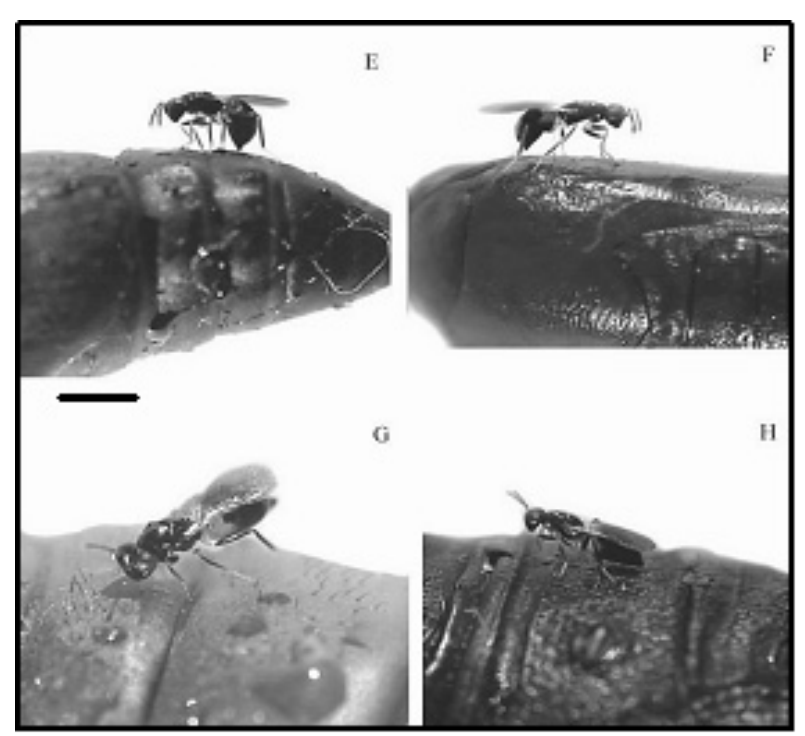

Figure 1 - $P$. elaeisis parasitizing pupae of $T$. arnobia (A), P. sequax (B), S. frugiperda (C), $H$. pearsoni $(\mathrm{D})$, A. argillacea $(\mathrm{E})$, A. gemmatalis $(\mathrm{F})$, B. mori $(\mathrm{G})$ and D. moderata $(\mathrm{H})$. Viçosa, State of Minas Gerais, Brazil. Bars $=1.0 \mathrm{~mm}$ 
Six adults of the parasitoid P. elaeisis were found parasitizing at the same time a $T$. leucoceraea pupae on an E. urophylla plant. A total de 194 adults of $P$. elaeisis emerged from this pupa after 23 days. This showed the gregarious behavior of this parasitoid, which was characterized by many larvae developing until maturity in a single host (Marchiori, 2005). P. elaeisis completed its cycle (21 to 23 days) with the hosts tested but with different number of adults emerged (63 to 1710 individuals per pupa) depending on the size of the pupa of each Lepidoptera species. This was, also, reported for this parasitoid with pupae of $D$. saccharalis, A. gemmatalis, $H$. virescens and $S$. frugiperda (Bittencourt and Berti Filho, 1999, 2004). This information was important because it demonstrated that $P$. elaeisis reproduced and it can be mass reared with hosts, which are easily reared in the laboratory. This species is generalist what may allow it to keep its population in the field even when their primary hosts are at low numbers. This generalist behavior and the high parasitism rate (85 to $100 \%$ ) of $P$. elaeisis characterize this parasitoid as an efficient agent of biological control. This parasitoid is polyphagous and it turns Lepidoptera pupae unfeasible, what makes important to study it for its use in outbreaks of eucalyptus defoliating caterpillars. The production and release of $P$. elaeisis could represent an efficient alternative to control eucalyptusdefoliating caterpillars due to the occurrence of different species of this group simultaneously.

\section{ACKNOWLEDGEMENTS}

We thank the Conselho Nacional de Desenvolvimento Científico e Tecnológico (CNPq), Coordenação de Aperfeiçoamento de Pessoal de Nível Superior (CAPES) and Fundação de Amparo à Pesquisa do Estado de Minas Gerais (FAPEMIG) for financial support and to Dr. Christer Hansson, Department of Zoology, Lund University, Sweden for the identification of the parasitoid.

\section{RESUMO}

Pupas de Thyrinteina arnobia (Stoll) e Thyrinteina leucoceraea Rindge (Lepidoptera: Geometridae) foram coletadas em Eucalyptus cloeziana F. Muell e Eucalyptus urophylla S.T. Blake, respectivamente. Espécimes de Palmistichus elaeisis Delvare and LaSalle (Hymenoptera: Eulophidae) emergiram de T. arnobia e foram encontrados sobre pupas de T. leucoceraea em plantas de eucalipto no campo. Esse é o primeiro relato de $P$. elaeisis parasitando pupas de $T$. arnobia e T. leucoceraea em condições naturais no Brasil. Além desses hospedeiros, P. elaeisis parasitou em laboratório Bombyx mori Linnaeus (Lepidoptera: Bombycidae), Anticarsia gemmatalis Hubner, Pseudaletia sequax Franclemont, Alabama argillacea Huebner (Lepidoptera: Noctuidae), Dirphia moderata Bouvier (Lepidoptera: Saturniidae) e Halysidota pearsoni Watson (Lepidoptera: Arctiidae). A produção de $P$. elaeisis e sua liberação em eucaliptais podem representar uma alternativa eficiente de controle de lagartas desfolhadoras de eucalipto.

\section{REFERENCES}

Berti Filho, E. (1985), O parasitismo no controle integrado de pragas florestais. Silvicultura, 10, 7-10.

Bittencourt, M. A. L. and Berti Filho, E. (1999), Preferência de Palmistichus elaeisis por pupas de diferentes lepidópteros pragas. Sci. Agric., 56, 12811283.

Bittencourt, M. A. L. and Berti Filho, E. (2004), Exigências térmicas para o desenvolvimento de Palmistichus elaeisis (Hymenoptera, Eulophidae) em pupas de cinco espécies de lepidópteros. Iheringia, Ser. Zool., 94, 321-323.

Dall'Oglio, O. T., Zanuncio, J. C., Freitas, F. A. and Pinto, R. (2003), Himenópteros parasitóides coletados em povoamentos de Eucalyptus grandis e mata nativa em Ipaba, estado de Minas Gerais. Cien. Flo.,13, 123129.

Delvare, G. and LaSalle, J. (1993), A new genus of Tetrastichinae (Hymenoptera: Eulophidae) from the Neotropical region, with the description of a new species parasitica on key pests of oil palm. J. Nat. Hist., 27, 435-444. 
Gauthier, N., LaSalle, J., Quicke, D. L. J. and Godfray, H. C. J. (2000), Phylogeny of Eulophidae (Hymenoptera: Chalcidoidea), with a reclassification of Eulophinae and the recognition that Elasmidae are derived eulophids. Syst. Entomo, 25, 521-539.

Godfray, H. C. J. (1994), Parasitoids, behavioral and evolutionary ecology. Princeton University Press, Princeton.

Hansson, C. (2004), Eulophidae of Costa Rica, 2. Mem. Am. Entomol. Inst., 75, 1-537.

LaSalle, J. (1993), North American genera of Tetrastichinae (Hymenoptera: Eulophidae). J. Nat. Hist., 28, 109-236.

LaSalle J. and Schauff, M. E. (1995), The Chalcidoid families. Eulophidae. In-The Hymenoptera of Costa Rica, eds. P.E. Hanson., I.D. Gauld. Oxford University Press, New York, pp. 315-329.

Marchiori, C. H. (2005), Nasonia vitripennis (Walker) (Hymenoptera: Pteromalidae) como parasitóide gregário em pupas de Peckia chrysostoma (Wiedemann) (Diptera: Sarchophagidae) no Brasil. Arq. Inst. Biol., 72, 269-270.
Mussury, R. M. and Fernandes, W. D. (2002), Occurrence of Diaretiella rapae (Mc'Intosh, 1855) (Hymenoptera: Aphidiidae) parasitising Lipaphis erysimi (Kaltenbach, 1843) and Brevicoryne brassicae (L. 1758) (Homoptera: Aphididae) in Brassica napus in Mato Grosso do Sul. Braz. Arch. Biol. Tech., 45, 41-46.

Noyes, J. S. (1998), Catalogue of the Chalcidoidea of the World. Eletronic Publication (CD-ROM). ETI, Amsterdam.

Pratissoli, D., Zanuncio, J. C., Vianna, U. R., Andrade, J. S., Moreira, T. B. and Andrade, G. S. (2005), Biological characteristics of Trichogramma pretiosum and Trichogramma acacioi (Hym.: Trichogrammatidae), parasitoids of the avocado defoliator Nipteria panacea (Lep.: Geometridae), on eggs of Anagasta kuehniella (Lep.: Pyralidae). Braz. Arch. Biol. Tech., 48, 7-13.

Van Driesche, R. G. V. and Bellows, T. S. (1996), Biological Control. Chapman and Hall, New York. 